\title{
PENGARUH SSP TEMATIK-INTEGRATIF TERHADAP KARAKTER DISIPLIN DAN TANGGUNG JAWAB SISWA KELAS III SD
}

\section{THE EFFECT OF THEMATIC-INTEGRATIVE SSP ON THE CHARACTERS OF DISCIPLINE AND RESPONSIBILITY OF YEAR III STUDENTS OF ESS}

\author{
An-Nisa Apriani, Muhammad Nur Wangid \\ SD Islam Al-Azhar 31 Yogyakarta,Universitas Negeri Yogyakarta \\ akunnisa@gmail.com,nurwangid2003@yahoo.com
}

\begin{abstract}
Abstrak
Penelitian ini bertujuan untuk mengetahui pengaruh penggunaan SSP tematik-integratif terhadap: (1) penanaman karakter disiplin dan (2) tanggung jawab siswa kelas III SD se-gugus 2 Kecamatan Banguntapan. Jenis penelitian ini adalah quasi experiment dengan desain pretest-posttest control group design. Teknik analisis data yang digunakan adalah uji Anova satu jalur dengan taraf signifikansi 0,05. Penelitiaan ini menunjukkan hasil sebagai berikut. (1) SSP tematik-integratif berpengaruh signifikan terhadap penananaman karakter disiplin. Hasil uji Anova pada skor posttest karakter disiplin antara kelompok kontrol, eksperimen I, dan eksperimen II menunjukkan bahwa nilai F sebesar 18,173 dengan db 86 dan taraf signifikansi 0,00. Nilai signifikansi lebih kecil dari 0,05. (2) SSP tematik-integratif berpengaruh signifikan terhadap penanaman karakter tanggung jawab antara kelompok kontrol, eksperimen I, dan eksperimen II. Hasil uji Anova pada skor posttest karakter tanggung jawab menunjukkan bahwa nilai $\mathrm{F}$ sebesar 17,809 dengan db 86 dan taraf signifikansi 0,00. Nilai signifikansi lebih kecil dari 0,05. Data tersebut dapat disimpulkan bahwa SSP tematik-integratif berpengaruh positif dan signifikan terhadap penanaman karakter disiplin dan tanggung jawab siswa kelas III SD Se-gugus 2 Kecamatan Banguntapan.
\end{abstract}

Kata kunci:SSP tematik-integratif, karakter disiplin dan tanggung jawab

\begin{abstract}
This research was aimed to find out the effect of thematic-integrative Subject Specific Pedagogy in inculcating the character of (1) discipline and (2) responsibility of year III students of elementary schools in cluster 2 in Banguntapan Subdistrict. This research was a quasi-experiment with a pretest and posttest control group design. The data analysis technique used was Anova test with significance level of 0.05. The results of the research were (1) Thematic Integrative Subject Specific Pedagogy had a significant effect in inculcating character of discipline. The result of the Anova test on the post-test score of discipline character among the control group, the experimental I and II groups showed that the value of $F$ was 18.173 with $d b 86$ and significance level of 0.00. The significance level was less than 0.05. (2) Thematic Integrative Subject Specific Pedagogy had a significant effect in inculcating character of responsibility among the control group, the experimental I and II groups. The result of the Anova test on the posttest score of the responsibility character showed that the value of $F$ was 17.809 with $d b 86$ and significance level of 0.00. The significance level was less than 0.05. Based on the data it could be concluded that there was a positive and significant effect of Thematic Integrative Subject Specific Pedagogy in inculcating characters of discipline and responsibility of year III students of elementary schools in cluster 2 in Banguntapan Subdistrict.
\end{abstract}

Key words: thematic integrative subject specific pedagogy, characters of discipline and responsibility. 


\section{Pendahuluan}

Pendidikan merupakan suatu kekuatan yang dinamis dalam kehidupan setiap manusia yang mempengaruhi perkembangan fisik, jiwa, sosial, dan moralitas. Keberadaan manusia saat ini dipengaruhi oleh pendidikan sebelumnya dan keberadaan manusia masa depan dipengaruhi oleh pendidikan saat ini.

Hal aktual yang dilakukan oleh Kementrian Pendidikan Nasional adalah melakukan pengembangan Kurikulum Tingkat Satuan Pendidikan (KTSP) menjadi Kurikulum 2013. Permendikbud No 67 Tahun 2013 menjelaskan bahwa kurikulum 2013 mampu menciptakan generasi yang berkualitas dan bermoral. Melalui kurikulum tersebut, siswa akan didorong menjadi manusia yang kreatif, produktif, inovatif, dan afektif melalui kompetensi-kompetensi yang berimbang antara spiritual, pengetahuan, sikap, dan keterampilan (Kemdikbud, 2013, p.4).

Pengembangan kurikulum 2013 mengacu pada beberapa alasan. Salah satunya, kompetensi di kurikulum KTSP belum menggambarkan secara holistik domain sikap, keterampilan, dan pengetahuan, beberapa kompetensi yang dibutuhkan sesuai dengan perkembangan kebutuhan (misalnya pendidikan karakter, keseimbangan soft skills dan hard skills, kewirausahaan) belum terakomodasi (Kemdiknas, 2013, p.88). Permasalahan tersebut menunjukkan bahwa proses pembelajaran sebelumnya lebih menekankan pada transfer pengetahuan (transfer of knowledge) dan kurang menanamkan nilai-nilai kehidupan (transfer of values) bagi siswa. Pengetahuan tanpa pemahaman nilainilai kehidupan akan menimbulkan perilakuperilaku yang menyimpang.

Perilaku menyimpang dapat terjadi di lingkungan sekolah dan diluar lingkungan sekolah. Penyimpangan perilaku di lingkungan sekolah dapat terjadi di kelas atau di luar kelas. Bukti empiris di lapangan menunjukkan bahwa generasi muda khususnya siswa sekolah dasar banyak melakukan penyimpangan perilaku. Adapun penyimpangan perilaku yang ditemukan di kalangan anak-anak dan orang dewasa diantaranya perkelahian pelajar, narkoba, kecurangan dalam ujian, suka membolos, korupsi, merokok, menonton film porno, dan plagiarisme (Kemdikbud, 2013, p.9).

Mengamati fenomena tersebut, pendidikan karakter sangat diperlukan di tengah-tengah kehidupan Bangsa yang sedang mengalami kemerosotan moral meskipun Indonesia sudah menjadi bangsa yang merdeka lebih dari lima dekade. Pemberlakuan kurikulum 2013 oleh Kementrian Pendidikan Nasional dari tingkat sekolah dasar diharapkan dapat mewujudkan siswa yang berkarakter. Selanjutnya, kurikulum 2013 juga menekankan pendekatan tematikintegratif dalam proses pembelajaran. Mengacu pada uraian tersebut, pendekatan pembelajaran yang digunakan dalam kurikulum 2013 adalah pendekatan tematik-integratif.

Menurut Min, Rashid, \& Nazri (2012, p 273), thematic approach is one of the teaching strategy that uses themes toward creating an active, interesting, and meaningful learning. Pendekatan tematik adalah salah satu strategi pembelajaran yang menggunakan tema melalui penciptaan pembelajaran yang aktif, menarik, dan bermakna. Dikatakan bermakna karena siswa akan dapat memahami konsep-konsep melalui pengalaman langsung dan nyata yang menghubungkan antar konsep.

Pembelajaran tematik-integratif penting untuk dilaksanakan karena mampu meningkatkan soft skill dan hard skill siswa berdasarkan proses pembelajarannya yang aktif, menarik, dan bermakna. Pernyataan tersebut juga memberi arti bahwa pembelajaran tematik-integratif memberi peluang besar bagi guru untuk mengembangkan tiga kompetensi yaitu pengetahuan, sikap, dan keterampilan yang berujung pada pribadi manusia yang memiliki good character.

Berdasarkan hasil pengamatan pada tanggal 9 Desember 2013 di beberapa SD di Kecamatan Banguntapan menunjukkan bahwa guru kelas awal menyiapkan perangkat pembelajaran tematik seperti silabus dan RPP dengan menggunakan tema dan menanamkan beberapa nilai karakter. Pelaksanaan pembelajarannya masih terlihat belum optimal dalam menanamkan nilai karakter melalui proses pembelajaran tematik. Perangkat pembelajaran yang digunakan guru juga tidak melalui analisa materi, kebutuhan dan karakteristik perkembangan siswa sehingga pembelajaran belum memberikan hasil yang lebih baik dalam menumbuhkembangkan pribadi yang berkarakter dan berakhlak mulia. Proses pembelajaran masih ditekankan dalam proses tranformasi pengetahuan.

Hasil pengamatan tersebut menunjukkan proses pembelajaran yang dilakukan guru selama ini belum memberi porsi yang cukup untuk menumbuhkembangkan soft skill siswa. Bukti empirisnya, banyak kasus penyimpangan nilai moral di kalangan siswa SD seperti tidak patuh 
pada aturan kelas dan sekolah, bermain dan berbicara saat guru menjelaskan materi, membolos, berkata kasar atau tidak sopan dengan teman, berkelahi, membuang sampah sembarangan, hadir tidak tepat waktu, dan tidak menyelesaikan tugas atau tidak mengerjakan PR.

Berangkat dari temuan masalah tersebut, maka dapat digambarkan bahwa guru perlu melakukan inovasi perubahan dalam mempersiapkan perangkat pembelajaran yang mendidik. Guru hendaknya lebih kreatif dan inovatif dalam penggunaan perangkat pembelajaran yang dikemas secara mendidik, komprehensif, dan spesifik baik tema dan nilai karakter yang ingin ditumbuhkembangkan di dukung dengan berbagai metode pembelajaran dan penanaman nilai karakter terbaik. Salah satu perangkat pembelajaran yang dapat diterapkan yaitu Subject Specific Pedagogy (SSP).

Menurut Permendiknas No. 8 Tahun 2009 Pasal 1 Ayat 6 bahwa SSP adalah pengemasan materi bidang studi menjadi perangkat pembelajaran yang komprehensif dan solid mencakup standar kompetensi, materi, strategi, metode, media, serta evaluasi (Kemdiknas, 2009, p.3). Selanjutnya, Margo (2014) dari English minor major at University of Detroit menambahkan bahwa: "Subject-specific Pedagogy is based on the "how to learn something". It's not only what we learn, it is also why and how we think it. Artinya, SSP di rancang berdasarkan pada "cara belajar sesuatu". SSP bukan hanya mengajarkan siswa tentang apa yang kita pelajari (pengetahuan), melainkan mengajak siswa untuk berpikir mengapa (sikap) dan bagaimana kita belajar tentang sesuatu yang lebih berguna bagi diri sendiri dan orang lain (keterampilan) melalui proses pembelajaran.

Sesuai dengan tuntutan kurikulum 2013, permendiknas No. 8 Tahun 2009 pasal 1 ayat 6 dan pendapat para ahli maka guru dituntut untuk menerapkan pendekatan tematik-integratif dengan perangkat pembelajaran yang di kemas secara spesifik dan mendidik dengan memberikan porsi yang cukup untuk menanamkan nilai moral guna membentuk pribadi yang berakhlak mulia. Perangkat pembelajaran yang dimaksud adalah SSP tematik-integratif.

SSP tematik-integratif merupakan perangkat pembelajaran mendidik yang dikemas secara komprehensif dan spesifik baik tema dan nilai karakter berdasarkan analisa kurikulum, materi dan siswa untuk mewujudkan pembelajaran tematik-integratif yang holistik, bermakna, dan menyenangkan. SSP tematik-integratif bertujuan membentuk siswa yang inovatif dan afektif melalui penguatan sikap, pengetahuan, dan keterampilan secara berimbang dan terintegrasi.

Penelitian pengujian SSP tematik integratif dalam menanamkan karakter siswa juga belum pernah dilakukan di Gugus 2 Kecamatan Banguntapan Bantul. Mempertimbangkan hal tersebut maka dicoba diteliti lebih jauh tentang pengaruh SSP tematik-integratif terhadap penanaman karakter siswa yang disiplin dan bertanggung jawab.

Penelitian ini bermaksud menguji secara empiris tentang pengaruh SSP tematik-integratif terhadap peningkatan karakter disiplin dan tanggung jawab siswa kelas III SD se-gugus 2 Kecamatan Banguntapan Bantul.

Berdasarkan latar belakang tersebut, masalah-masalah dalam penelitian ini dapat diidentifikasi: (1) Guru masih sebatas menyiapkan perangkat pembelajaran tematik tanpa analisa perkembangan dan kebutuhan siswa dalam proses pembelajaran, (2) Proses pembelajaran selama ini lebih menekankan pada transfer pengetahuan (transfer of knowledge) dan kurang menanamkan nilai-nilai kehidupan (transfer of values) bagi siswa, (3) Membudayanya perilaku ketidakdisiplinan dan rendahnya rasa tanggung jawab individu, dan (4) belum terdapat bukti empiris terkait pengaruh SSP tematikintegratif terhadap penanaman karakter disiplin dan tanggung jawab siswa SD kelas III.

Penelitian ini dibatasi pada permasalahan penyimpangan perilaku siswa SD yaitu membudayanya perilaku ketidakdisiplinan dan rendahnya rasa tanggung jawab individu dan belum terdapat bukti empiris terkait pengaruh SSP tematik-integratif terhadap penanaman karakter disiplin dan tanggung jawab siswa SD kelas III. Tujuan penelitian ini adalah untuk mengetahui pengaruh penggunaan SSP tematik-integratif terhadap penanaman karakter disiplin siswa kelas III SD dan pengaruh penggunaan SSP tematik-integratif terhadap penanaman karakter tanggung jawab siswa kelas III SD.

Kurikulum 2013 menuntut guru untuk mampu memfasilitasi dan mengembangkan kompetensi karakter yang sudah ditentukan dalam pembelajaran. Untuk menfasilitasi nilainilai karakter dalam pembelajaran dibutuhkan perangkat pembelajaran yang tepat. Salah satu model perangkat yang dapat membantu guru dalam mengembangkan kompetensi tersebut adalah Subject Specific Pedagogy (SSP). 
California State university (Wibowo, 2011, p.40) mengungkapkan bahwa SSP yang dikenal dengan PCK merupakan bentuk pengetahuan dan bagian dari proses berfikir seorang guru. Oleh karena itu, SSP adalah produk dinamis yang dapat berubah sesuai dengan tingkat penguasaan seorang guru terhadap suatu mata pelajaran.

Renee (2014) menambahkan bahwa: "Subject-specific pedagogy is subject matter that is designed to instruct specific group and interest". Artinya, SSP adalah perangkat pembelajaran yang dirancang untuk membelajarkan kelompok dan kepentingan tertentu. Kelompok yang dimaksud adalah siswa kelas III dan kepentingannya adalah menanamkan karakter disiplin dan tanggung jawab pada diri siswa SD kelas III.

Selanjutnya, Margo (2014) juga menjelaskan bahwa: "Subject-specific Pedagogy is based on the "how to learn something". It's not only what we learn, it is also why and how we think it. SSP di rancang berdasarkan pada "cara belajar sesuatu". SSP bukan hanya mengajarkan siswa tentang apa yang kita pelajari, melainkan mengajak siswa untuk berpikir mengapa dan bagaimana kita belajar tentang sesuatu yang lebih berguna bagi diri sendiri dan orang lain melalui proses pembelajaran.

Sesuai kurikulum 2013 yang berlaku saat ini, SSP yang diterapkan pada pembelajaran adalah SSP tematik-integratif. SSP tematik integratif adalah SSP yang dikembangkan dan dikemas dalam rangka melaksanakan pembelajaraan tematik-integratif.

SSP tematik integrative sebagai pengemasan bidang studi menjadi perangkat pembelajaran yang komprehensif dan mendidik dalam rangka melaksanakan pembelajaraan tematikintegratif mencakup standar kompetensi, materi, strategi, metode, media, dan evaluasi (instrumen hasil belajar). SSP Tematik-integratif yang diperlukan dalam pengembangan kompetensi inti meliputi komponen silabus, RPP, media pembelajaran, materi pelajaran, lembar kerja siswa, dan instrument penilaian yang di desain secara spesifik baik tema dan nilai karakter yang akan ditumbuhkembangkan melalui proses pembelajaran tematik-integratif.

Randle (2010, p.85) memperjelas tentang pembelajaran tematik-integratif, yakni: Integrated Thematic Instruction-based curricula stress the integration of all disciplines to present students with learning experiences that are based in real-world application and structured to encourage higher-order learning and the development of critical habits students need to become lifelong learners.

Pernyataan tersebut berarti bahwa pembelajaran tematik-integratif menekankan pada pengintegrasian semua disiplin ilmu dengan pengalaman belajar yang berbasis pada aplikasi dan stuktur dunia nyata, sehingga mendorong pembelajaran menjadi lebih baik dan mengembangkan kebiasaan dan kebutuhan siswa untuk menjadi pembelajar sepanjang hayat.

Pembelajaran tematik-integratif memiliki beberapa keunggulan. Drake (2012, p.7) menjelaskan bahwa: "An integrated curriculum that would motivate students because it was relevant and followed the principles of constructivism". Artinya, pembelajaran dengan kurikulum integrasi akan memotivasi siswa untuk belajar karena pembelajaran integrasi relevan dengan kebutuhan dan perkembangan anak serta mengikuti prinsip-prinsip kontruktivisme sehingga siswa mendapat kesempatan untuk mengkonstruk penegtahuannya sendiri melalui pengalaman dan lingkungan.

Pelaksanaan pembelajaran tematik berdampak besar bagi guru sebagai subjek utama dalam merancang dan melaksanakan pembelajaran tematik.Pembelajaran tematik membutuhkan guru kreatif, inovatif, dan produktif dalam mempersiapkan perangkat pembelajaran, sumber belajar, dan media untuk membantu siswa dalam menggali dan membentuk pengetahuan secara holistik. Artinya, guru perlu mempersiapkan segala sesuatu yang dibutuhkan dalam pembelajaran tematik-integratif yaitu Subject Specific Pedagogy (SSP) tematik integratif agar proses pembelajaran terlaksana lebih holistik, efektif, bermakna, menarik, dan menyenangkan.

Pendekatan saintifik dalam proses pembelajaran ini juga sering disebut sebagai ciri khas dari Kurikulum 2013. Joyce, B \& Weil, M (1996, p.42) menjelaskan bahwa: "Scientific method can be taught and has positive effects on the acquisition of information, concepts, and attitudes". Metode ilmiah dapat diajarkan dan memiliki efek positif pada perolehan informasi, konsep, dan sikap. Artinya, pendekatan ilmiah diyakini mampu mengembangkan ranah sikap, keterampilan, dan pengetahuan siswa dengan tujuan mengembangkan good character.

Kemdikbud (2013, pp.9-15) menambahkan bahwa pendekatan ilmiah (scientific approach) dalam pembelajaran di dalamnya mencakup komponen: mengamati, menanya, 
mengumpulkan informasi atau mencoba, menalar, menyimpulkan, dan mengkomunikasikan.

Pendidikan karakter harus berlangsung secara terus menerus tanpa kata henti untuk mewujudkan pribadi siswa yang berkualitas baik. Penjelasan tersebut sesuai dengan pernyataan Bohlin (2005, p.159) bahwa karakter merupakan ciri khas seseorang yang membedakan kualitas antar individu. Lebih lanjut pernyataan tersebut juga menekankan bahwa karakter tidak hanya apa yang terlihat dipermukaan, melainkan lebih kedalam yakni kepribadian individu tersebut. Lickona (1991, p.6) juga menambahkan tentang pentingnya pendidikan karakter yang memuat tujuan yang mulia yaitu "Moral education is not a new idea. It is, in fact, all of the education itself. Down through history, in countries around the world, education has two major goals is to help young people to be smart and to help them become better".

Nilai-nilai yang memiliki unsur kebaikan perlu ditanamkan pada diri anak sejak usia dini untuk dijadikan pedoman berpikir, berkata, dan berperilaku dalam keseluruhan kehidupan. $\mathrm{Na}$ mun, nilai karakter yang akan difokuskan dalam penelitian yaitu disiplin dan tanggung jawab.

Lickona (1991, p.110) menjelaskan bahwa: a moral education approach to discipline uses disciplin as a tool for teaching the values of respect and responsibility. Artinya, pembelajaran nilai disiplin menggunakan disiplin sebagai alat untuk mengajarkan nilai-nilai hormat dan tanggung jawab.

Nucci \& Narvaez (2008, p.197) menyatakan bahwa: "In developmental discipline children are viewed as intrinsically motivated to learn achieve competence and to establish mutually caring relationship in a supportive and caring environment." Artinya, pengembangan disiplin pada diri anak dipandang baik karena perilaku disiplin dapat menumbuhkan motivasi intrinsik bagi siswa untuk belajar lebih giat guna mencapai tujuan, membangun hubungan yang mendukung dan peduli terhadap lingkungan.

Penguasaan tanggung jawab penting ditekankan untuk siswa sekolah dasar. tanggung jawab berarti berani, siap, dan teguh hatinya dalam menerima putusan dan tindakan yang dilakukan secara sengaja atau tidak sengaja. Maksudnya, siswa dikatakan bertanggung jawab jika dirinya sadar mengambil keputusan dan mau menghadapi segala akibat yang terjadi. Siswa tidak akan lari dari situasi yang diakibatkan oleh perbuatannya dan mau menanggung akibat serta tidak menyalahkan orang lain (Suparno, 2003, p.114).

Untuk dapat memenuhi tanggung jawab, anak harus punya kemampuan melakukan tugas atau pekerjaan. Anak perlu memiliki keterampilan untuk menyelesaikan tugas dan sadar terhadap resiko jika pekerjaan tidak dikerjakan atau memberikan hasil kerja yang rendah. Anak yang belajar bertanggung jawab akan meningkatkan rasa untuk mampu melakukan sesuatu (Clemes \& Bean, 2001, p.68). Anak yang belajar bertanggung jawab akan membuat keputusan yang lebih baik.

Berhasil tidaknya penanaman nilai karakter dalam proses pembelajaran. Guru memiliki peran yang penting bagi setiap proses penanaman nilai karakter. Praktik pembelajaran karakter di dalam kelas menuntut guru untuk memperhatikan cara yang tepat dalam bertindak sebagai berikut (Koesoemo, 2007, pp.231-232): (1) guru menjadi pengasuh, teladan, dan pembimbing.(2) menciptakan komunitas moral. Guru perlu membantu siswa untuk saling menghargai, memiliki rasa hormat, dan bertanggung jawab atas kelompok. (3) menegakkan disiplin moral melalui pelaksanaan kesepakatan yang telah ditentukan sebagai aturan bersama. (4) menciptakan lingkungan kelas yang melibatkan para siswa dalam mengambil keputusan dan bertanggung jawab terhadap kelas sebagai tempat belajar yang menyenangkan. (5) mengajarkan nilai karakter dengan cara mengagali materi pembelajaran dari mata pelajaran yang kaya dengan nilai-nilai moral. (6) mempergunakan metode pembelajaran yang tepat dalam menanamkan nilai-nilai moral.

Penggunaan SSP tematik-integratif dalam pembelajaran untuk menanamkan karakter perlu didukung dengan beberapa teori. Teori belajar yang mendukung pembelajaran tematik integratif yaitu teori konstrukstivisme dan humanisme. Sedangkan teori belajar yang mendukung proses penanaman karakter yaitu teori behaviorisme dan kognitif sosial Bandura.

Teori perkembangan Piaget mewakili konstruktivisme, yang memandang perkembangan kognitif sebagai suatu proses di mana anak secara aktif membangun sistem makna dan pemahaman realitas melalui interaksi siswa dengan lingkungan, fenomena, dan pengalaman. Schunk (2012, p.328) mengungkapkan bahwa pemahaman konsep yang mendalam dikembangkan melalui pengalaman-pengalaman belajar otentik dan bermakna. 
Selanjutnya, pengetahuan yang telah ada sebagai hasil dan proses elemen dasar ini akan lebih berkembang ketika mereka berinteraksi dengan lingkungan sosial mereka. Menurut Vygotsky (Schunk, 2012, p.254), peserta didik adalah seseorang yang mempunyai rasa ingin tahu tinggi, sangat aktif dalam pembelajaran, selalu ingin menemukan sendiri, dan mengembangkan pemahaman baru.

Pembelajaran berdasarkan teori humanistikjuga cocok untuk diterapkan untuk pembelajaran yang besifat pembentukan kepribadian, hati nurani, perubahan sikap, dan analisis terhadap fenomena sosial (Sugihartono, 2012, p.120). Melalui pembelajaran humanistik, siswa di harapkan menjadi manusia yang berani, mengatur pribadinya sendiri secara bertanggung jawab tanpa mengurangi hak orang lain, dan mematuhi aturan yang berlaku (disiplin). Indikator dari keberhasilan aplikasi ini adalah siswa merasa senang bergairah, berinisiatif dalam belajar dan terjaadi perubahan pola pikir, perilaku dan sikap atas kemauan sendiri.

Slavin, (2000, p.143) menambahkan bahwa belajar merupakan akibat adanya interaksi antara stimulus dan respon. Seseorang dianggap telah belajar sesuatu jika dia dapat menunjukkan perubahan perilakunya.

Behaviorisme merupakan salah satu pendekatan di dalam psikologi pendidikan yang didasari keyakinan bahwa anak dapat dibentuk sesuai dengan apa yang diinginkan oleh orang membentuknya. Dengan kata lain, semua perilaku diperoleh individu setelah berinteraksi dengan lingkungan yang telah dikondisikan.

Dalam kaitannya mengenai pendidikan karakter, teori belajar behaviorisme yang digunakan lebih cenderung kepada teori belajar yang dikemukakan oleh Pavlov yang dinyatakan bahwa perilaku dapat dibentuk melalui kondisioning atau kebiasaan dan Skinner yang menyatakan bahwa perilaku dapat dibentuk melalui penguatan. Penerapan pendidikan karakter disekolah melalui upaya keteladanan, pembiasaan, pengalaman, pengkondisian lingkungan, dan penguatan seperti penghargaan, kiranya akan lebih efektif karena dalam metode ini pembelajaran nilai-nilai karakter tidak hanya pada tataran kognitif melainkan juga dipahami secara utuh dan menyeluruh oleh seluruh civitas akademika yang ada disekolah tanpa menafikan aspek pokok yang harus dipenuhi dalam pendidikan, yaitu mencakup aspek kognitif, afektif dan psikomotorik.
Ada 3 parameter yang diperkenalkan Pavlov melalui teori Classical Conditioning (Crooks \& Stein, 1991, p.225) yaitu reinforcement (penguatan), extinction (penghilangan) dan spontaneous recovery (pengembalian spon$\tan$ ). Menurut Pavlov, respon terkondisi yang paling sederhana diperoleh dari reinforcement (penguatan) yang terus berulang. Pembentukan respon terkondisi umumnya cersifat bertahap (gradual). Jika penguatan dihentikan dan stimulus terkondisi dimunculkan sendiri tanpa stimulus tak terkondisi ada kemungkinan frekuensi respon terkondisi akan menurun dan hilang. Proses ini disebut penghilangan (extinction).

Teori operan kondisioning Skinner juga memberi banyak kontribusi untuk praktik pembelajaran yang mengembangkan pribadi yang baik. Crooks \& Stein (1991, p.532) menambahkan bahwa The perspective of behaviorism conditioning is responsible for the development of personality. Artinya, perspektif pengkondisian behaviorisme bertanggung jawab untuk pengembangan kepribadian. Teori belajar operan kondisioning menggunakan konsekuensi, penguatan, dan hukuman.

Teori selanjutnya adalah teori belajar kognitif sosial yang menyatakan bahwa seseorang belajar dari lingkungan sosial mereka. Dalam teori Bandura, fungsi manusia dipandang sebagai serangkaian interaksi timbal balik antara faktor-faktor pribadi, perilaku, dan lingkungan (Schunk, 2012. p.222).Manusia dapat belajar baik secara langsung dari pengalaman yang dialami oleh individu itu sendiri maupun belajar dari pengalaman orang lain serta lingkungan sekitar individu. Sebagian besar upaya belajar manusia terjadi melalui peniruan (imitation) dan penyajian contoh (modeling). Menurut Hergenhahn \& Olson $(2012$, p.361) model di sini diartikan sebagai apa saja yang menyampaikan informasi, seperti orang (guru, orang tua atau teman), gambar, dan instruksi.

\section{Metode}

Jenis Penelitian

Penelitian ini menggunakan pendekatan kuantitatif. Jenis penelitian adalah kuasi eksperimen dengan pretest postest control group design.

Waktu dan Tempat Penelitian

Penelitian ini dilakukan di SD Negeri Sokowaten Baru dan SD Negeri Banguntapan. 
Penelitian dilaksanakan pada bulan April-Mei 2014.

\section{Target/Subjek Penelitian}

Populasi yang digunakan dalam penelitian ini adalah siswa kelas III SD se-gugus 2 Kecamatan Banguntapan. Sampel dalam penelitian ini yaitu siswa kelas III SD N Ssokowaten Baru dan SD N Banguntapan. Teknik pengampilan sampel yang digunakan adalah teknik clusterrandom sampling.

Prosedur Penelitian

Jenis rancangan penelitian adalah pretest postest control group design. Adapun prosedur penelitian ini melalui empat tahap yaitu: (1) tahap persiapan, (2) pemberian pretest, (3) pemberian perlakuan (eskperimen), dan (4) pemberian posttest. Tahap eksperimen dilakukan perlakuan dengan menggunakan SSP tematikintegratif pada kelas eksperimen I dan II, serta dilakukan pembelajaran dengan perangkat pembelajaran tematik pada kelas kontrol.

Data, Teknik, dan Instrumen Pengumpulan

Data penelitian ini berupa data utama dan data pendukung. Data utama berupa data perilaku siswa sebelum perlakuan diperoleh melalui pengamatan awal (pretest), dan data setelah perlakuan diperoleh melalui pengamatan akhir (posttest) yang menunjukkan karakter disiplin dan tanggung jawab. Data pendukung berupa data pengamatan perilaku siswa yang menunjukkan karakter disiplin dan tanggung jawab serta aktivitas guru selama proses pembelajaran.Teknik pengumpulan data yang digunakan adalah observasinon partisipatif yaitu observasi aktivitas siswa dan guru. Pedoman observasi yang dipakai adalah pedoman observasi check list, rating scale dan mechanical device. Pedoman observasi yang telah dibuat berupa pedoman observasi perilaku siswa yang menunjukkan karakter disiplin dan tanggung jawab pada saat pelaksanaan pembelajaran dan lembar observasi aktivitas guru dalam pembelajaran. Mechanical device berupa rekaman kegiatan penelitian dari pretest, pelaksanaan penelitian sejak awal sampai akhir pembelajaran, dan posttest yang berwujud foto penelitian.

Teknik Analisis Data

Teknik analisis data dilakukan untuk memenuhi jawaban dari dugaan adanya pengaruh penggunaan SSP tematik-integratif terhadap penanaman karakter disiplin dan tanggung jawab siswa kelas III SD se-gugus 2 Kecamatan Banguntapan. Sebelum dilakukan analisis data, dilakukan uji prasyarat analisis dengan menggunakan uji normalitas dan uji homogenitas. Pada pengujian normalitas sebaran ini menggunakan rumus Kolmogorov-Smirnov, sedangkan uji homogenitas menggunakan Levene Test.

Analisis yang dipakai dalam penelitian ini ada dua, yaitu analisis deskriptif dan analisis inferensial. Pendeskripsian dilakukan dengan menggunakan komputer program SPSS versi 17.0. untuk mendapatkan mean, standar deviasi, modus, dan median dari masing-masing variabel. Distribusi frekuensi data baik perilaku siswa dan aktivitas guru dibuat dengan membuat kelas interval. Untuk melihat tingkat kecenderungan skor dilakukan dengan menggunakan lima kategori menurut Sukarjo (2006, p.53) dengan rumus sebagaimana pada tabel 1 .

Tabel 1. Konversi Skor Aktual Menjadi Skor Skala LimaBerdasarkan Simpangan Baku (SB)

\begin{tabular}{|c|c|c|}
\hline Interval Skor & Nilai & Kate \\
\hline $\mathrm{X}>\mathrm{Mi}+1,8 \mathrm{Sbi}$ & $\mathrm{A}$ & Sangat baik \\
\hline $\begin{array}{c}\mathrm{Mi}+0,6 \mathrm{SBi}<\mathrm{X} \leq \mathrm{Mi}+ \\
1,8 \mathrm{SBi}\end{array}$ & B & Baik \\
\hline $\begin{array}{c}\mathrm{Mi}-0,6 \mathrm{SBi}<\mathrm{X} \leq \mathrm{Mi}+ \\
0,6 \mathrm{SBi}\end{array}$ & $\mathrm{C}$ & Cukup baik \\
\hline $\begin{array}{c}\mathrm{Mi}-1,8 \mathrm{SBi}<\mathrm{X} \leq \mathrm{Mi}- \\
0,6 \mathrm{SBi}\end{array}$ & $\mathrm{D}$ & Kurang baik \\
\hline $\mathrm{X} \leq \mathrm{Mi}-1,8 \mathrm{SBi}$ & $\mathrm{E}$ & $\begin{array}{l}\text { angat kura } \\
\text { baik }\end{array}$ \\
\hline \multicolumn{3}{|c|}{$\begin{array}{l}\text { Mi = mean ideal, dihitung dengan mengguna- } \\
\text { kan rumus: }\end{array}$} \\
\hline \multicolumn{3}{|c|}{$\begin{array}{l}\mathrm{SBi}=\text { simpangan baku ideal, ditentukan dengan } \\
\text { rumus: }\end{array}$} \\
\hline \multicolumn{3}{|c|}{$\mathrm{SBi}=1 / 6$ (skor maks ideal - skor minimal ideal } \\
\hline \multicolumn{3}{|c|}{$\begin{array}{l}\text { Analysis of Variance (Anova). Uji ANAVA } \\
\text { dipilih untuk menguji perbedaan skor rata-rata } \\
\text { karakter disiplin dan tanggung jawab dari dua } \\
\text { kelompok sampel.Uji ANAVA yang digunakan } \\
\text { adalah Analisis Variansi Satu jalur yaitu anali- } \\
\text { sis variansi yang hanya menguji satu faktor } \\
\text { variabel independen dalam penelitian. }\end{array}$} \\
\hline
\end{tabular}

\section{Hasil dan Pembahasan}

Hasil analisis statistik deskriptif skor pretest dan posttest karakter disiplin dan tanggung jawab pada kelompok kontrol dan kelompok eksperimen (I dan II) meliputi jumlah subjek $(\mathrm{N})$, mean, mode (Mo), median (Mdn), 
skor minimal, dan skor maksimal. Hasil analisis statistik deskripstif skor pretest dan posttest karakter disiplin dapat dilihat dalam tabel 2.

Tabel 2. Analisis Statistik Deskriptif SkorPretest dan Posttest Karakter Disiplin

Kelompok Kontrol, Eksperimen I, dan Eksperimen II

\begin{tabular}{ccccc}
\hline Kelompok & Data & Pretest & Posttest & Peningkatan \\
\hline Kontrol & $\mathrm{N}$ & 30 & 30 & 30 \\
& Mean & 68,13 & 68,83 & 0,70 \\
& Mdn & 68 & 69 & 1 \\
& Mo & 64 & 67 & 3 \\
& Min & 61 & 62 & 1 \\
& Max & 77 & 78 & 1 \\
Eksperimen & $\mathrm{N}$ & 25 & 25 & 25 \\
I & Mean & 66,56 & 72,36 & 5,8 \\
& Mdn & 65 & 72 & 7 \\
& Mo & 68 & 68 & 0 \\
Eksperimen & Min & 58 & 67 & 9 \\
II & Max & 75 & 79 & 4 \\
& N & 32 & 32 & 32 \\
& Mean & 68,78 & 74,75 & 5,97 \\
& Mdn & 73 & 74 & 1 \\
& Mo & 66 & 73 & 7 \\
& Min & 60 & 67 & 7 \\
& Max & 75 & 83 & 8 \\
\hline & & & &
\end{tabular}

Tabel 2 menjelaskan perbandingan antara skor pretest dan skor posttestkarakterdisiplin yang dimiliki kelompok kontrol dan kelompok eksperimen dapat diketahui. Pada saat pretest karakter disiplin kelompok kontrol, skor tertinggi 77 dan skor terendah 61 sedangkan pada saat posttest skor tertinggi 78 dan skor terendah 62. Skor tertinggi dan terendah kelompok kontrol mengalami peningkatan. Tetapi, peningkatan skor tidak terlalu tinggi.

Pada saat pretest karakter disiplin kelompok eksperimen I mendapatkan skor tertinggi 75 dan skor terendah 58, sedangkan pada saat posttest karakter disiplin skor tertinggi 79 dan skor terendah 67. Pada kelompok eksperimen II, saat pretest mendapatkan skor tertinggi 75 dan skor terendah 60 , sedangkan pada saat posttest mendapatkan skor tertinggi menjadi 83 dan skor terendah 67. Dari data tersebut dapat dilihat bahwa peningkatan skor tertinggi dan terendah kelompok eksperimen ( I dan II) lebih besar daripada kelompok kontrol.

Skor rata-rata antara pretest dan posttest kelompok kontrol dan kelompok eksperimen (I dan II) juga mengalami peningkatan. Pada saat pretest skor rata-rata kelompok kontrol sebesar 68,13 , sedangkan pada saat posttest skor ratarata sebesar 68,83 . Skor rata-rata kelompok kontrol mengalami peningkatan sebesar 0,70. Sementara itu, skor rata-rata pretest kelompok eksperimen I sebesar 66,56, sedangkan skor rata-rata posttest kelompok eksperimen I sebesar 72,36. Skor rata-rata kelompok eksperimen I mengalami peningkatan sebesar 5,8. Selain itu, skor rata-rata kelompok eksperimen II sebesar 68,78 , sedangkan skor rata-rata posttest kelompok eksperimen II sebesar 74,75. Skor rata-rata kelompok eksperimen II mengalami peningkatan sebesar 5,97. Dari data tersebut dapat dilihat bahwa peningkatan skor rata-rata kelompok eksperimen (I dan II) lebih besar daripada peningkatan skor rata-rata kelompok kontrol.

Perolehan skor pretest dan posttest karakter disiplin kemudian dilakukan pengelompokan untuk mengetahui kategori kecenderungan skor berada dalam kategori sangat kurang, kurang, cukup, baik, atau sangat baik. Berikut disajikan kecenderungan skor pretest karakter disiplin kelompok eksperimen I, eksperimen II, dan kontrol

Tabel 3. Kecenderungan Skor PretestDisiplin

\begin{tabular}{cccc}
\hline Kelompok & Kategori & Interval & Frek \% \\
\hline \multirow{4}{*}{ Kontrol } & Cukup & $>48,4-61,6$ & 3.3 \\
& Baik & $>61,6-74,8$ & 80 \\
& Sangat & $>74,8-77$ & 16,7 \\
& Cukup & $>48,4-61,6$ & 28 \\
Eksperimen I & Baik & $>61,6-74,8$ & 64 \\
& Sangat & $>74,8-77$ & 8 \\
& Cukup & $>48,4-61,6$ & 3,1 \\
Eksperimen II & Baik & $>61,6-74,8$ & 87,5 \\
& Sangat & $>74,8-77$ & 9,4 \\
\hline
\end{tabular}

Tabel 3 menunjukkan kecenderungan skor pretest karakter disiplin yang diperoleh kelompok ekperimen I, eksperimen II, dan kontrol masuk kategori baik. Hal tersebut dari frekuensi (\%) siswa yang masuk dalam kategori baik lebih tinggi dibandingkan kategori lain.

Saat posttest disiplin kecenderungan kelompok berubah. Berikut disajikan kecenderungan skor posttest masing-masing kelompok.

Tabel 4. Kecenderungan Skor PosttestDisiplin

\begin{tabular}{cccc}
\hline Kelompok & Kategori & Interval & Frek\% \\
\hline Kontrol & Baik & $>61,6-74,8$ & 90 \\
& Sangat & $>74,8-77$ & 10 \\
Eksperimen I & Baik & $>61,6-74,8$ & 60 \\
& Sangat & $>74,8-77$ & 40 \\
Eksperimen II & Baik & $>61,6-74,8$ & 50 \\
& Sangat & $>74,8-77$ & 50 \\
\hline
\end{tabular}

Tabel 4 menunjukkanfrekuensi (\%) yang didapatkan masing-masing kelompok berbeda- 
beda. Kelompok kontrol mendapatkan frekuensi tertinggi pada kategori baik, sedangkan kelas ekperimen I dan eksperimen II mendapatkan frekuensi tertinggi pada kategori sangat baik.

Hasil analisis statistik deskripstif skor pretest dan posttest karakter tanggung jawab dapat di lihat dalam tabel 5.

Tabel 5. Analisis Statistik Deskripstif Skor Pretest dan Posttest karakter Tanggung Jawab

Kelompok Kontrol, Eksperimen I, dan Eksperimen II

\begin{tabular}{ccccc}
\hline Kelompok & Data & \multicolumn{1}{c}{ Pretest } & Posttest & Peningkatan \\
\hline Kontrol & N & 30 & 30 & 30 \\
& Mean & 41,03 & 41,53 & 0,50 \\
& Mdn & 42 & 42,5 & 0,5 \\
& Mo & 42 & 46 & 4 \\
& Min & 33 & 33 & 0 \\
Eksperimen & Max & 49 & 46 & -3 \\
I & N & 25 & 25 & 25 \\
& Mean & 43,04 & 47,78 & 4,74 \\
& Mdn & 38 & 48 & 10 \\
Eksperimen & Mo & 40 & 53 & 13 \\
II & Min & 35 & 40 & 5 \\
& Max & 51 & 53 & 2 \\
& N & 32 & 32 & 32 \\
& Mean & 41,03 & 47,28 & 6,25 \\
& Mdn & 44 & 48 & 4 \\
& Mo & 44 & 52 & 8 \\
& Min & 35 & 39 & 4 \\
& Max & 50 & 52 & 2 \\
\hline
\end{tabular}

Tabel 5 menjelaskan tentang perbandingan antara skor pretest dan skor posttest karakter tanggung jawab yang dimiliki kelompok kontrol dan kelompok eksperimen dapat diketahui. Pada saat pretest karakter tanggung jawab kelompok kontrol, skor tertinggi 49 dan skor terendah 33 sedangkan pada saat posttest skor tertinggi 46 dan skor terendah 33. Skor tertinggi kelompok kontrol mengalami penurunan. Skor terendah kelompok kontrol tidak mengalami penurunan atau kenaikan.

Pada saat pretest karakter tanggung jawab kelompok eksperimen I mendapatkan skor tertinggi 51 dan skor terendah 35, sedangkan pada saat posttest karakter tanggung jawab skor tertinggi 53 dan skor terendah 40. Pada kelompok eksperimen II, saat pretest mendapatkan skor tertinggi 50 dan skor terendah 35, sedangkan pada saat posttest mendapatkan skor tertinggi menjadi 52 dan skor terendah 39. Dari data tersebut dapat dilihat bahwa peningkatan skor tertinggi dan terendah kelompok eksperimen (I dan II) lebih besar daripada kelompok kontrol.

Skor rata-rata antara pretest dan posttest kelompok kontrol dan kelompok eksperimen (I dan II) juga mengalami peningkatan. Pada saat pretest skor rata-rata kelompok kontrol sebesar 41,03 , sedangkan pada saat posttest skor ratarata sebesar 41,53. Skor rata-rata kelompok kontrol mengalami peningkatan sebesar 0,50. Sementara itu, skor rata-rata pretest kelompok eksperimen I sebesar 43,04, sedangkan skor rata-rata posttest kelompok eksperimen I sebesar 47,78. Skor rata-rata kelompok eksperimen I mengalami peningkatan sebesar 4,74. Selain itu, skor rata-rata kelompok eksperimen II sebesar 41,03, sedangkan skor rata-rata posttest kelompok eksperimen II sebesar 47,28. Skor rata-rata kelompok eksperimen II mengalami peningkatan sebesar 6,25. Dari data tersebut dapat dilihat bahwa peningkatan skor ratarata kelompok eksperimen ( I dan II) lebih besar daripada peningkatan skor rata-rata kelompok kontrol.

Perolehan skor pretest dan posttest karakter tanggung jawab kemudian dilakukan pengelompokan untuk mengetahui kategori kecenderungan skor berada dalam kategori sangat kurang, kurang, cukup, baik, atau sangat baik. Berikut disajikan kecenderungan skor pretest kelompok eksperimen I, eksperimen II, dan control.Berikut disajikan kecenderungan skor pretest karakter tanggung jawab kelompok eksperimen I, eksperimen II, dan kontrol.

Tabel 6. Kecenderungan Skor Pretest Tanggung Jawab

\begin{tabular}{cccc}
\hline Kelompok & Kategori & Interval & Frekuensi \% \\
\hline Kontrol & Cukup & $>30,8-39,2$ & 26,7 \\
& Baik & $>39,2-47,6$ & 63,3 \\
& Sangat & $>47,6$ & 10 \\
Eksperimen I & Cukup & $>30,8-39,2$ & 20 \\
& Baik & $>39,2-47,6$ & 68 \\
& Sangat & $>47,6$ & 12 \\
Eksperimen II & Cukup & $>30,8-39,2$ & 40,6 \\
& Baik & $>39,2-47,6$ & 50 \\
& Sangat & $>47,6$ & 9,4 \\
\hline
\end{tabular}


Tabel 6 menunjukkan kecenderungan skor pretest karakter tanggung jawab yang diperoleh kelompok ekperimen I, eksperimen II, dan kontrol masuk kategori baik. Hal tersebut dari frekuensi (\%) siswa yang masuk dalam kategori baik lebih tinggi dibandingkan kategori lain.

Saat posttest karakter tanggung jawab kecenderungan kelompok berubah. Berikut disajikan kecenderungan skor posttest masingmasing kelompok.

Tabel 7. Kecenderungan Skor Posttest Tanggung Jawab

\begin{tabular}{cccc}
\hline Kelompok & Kategori & Interval & Frekuensi \% \\
\hline Kontrol & Cukup & $>30,8-39,2$ & 23,3 \\
& Baik & $>39,2-47,6$ & 76,7 \\
Eksperimen I & Baik & $>39,2-47,6$ & 40 \\
& Sangat & $>47,6$ & 60 \\
Eksperimen II & Baik & $>39,2-47,6$ & 46,9 \\
& Sangat & $>47,6$ & 53,1 \\
\hline
\end{tabular}

Tabel 7 menunjukkan frekuensi (\%) yang didapatkan masing-masing kelompok berbedabeda. Kelompok kontrol mendapatkan frekuensi tertinggi pada kategori baik, sedangkan kelas ekperimen I dan eksperimen II mendapatkan frekuensi tertinggi pada kategori sangat baik.

Pengamatan juga dilakukan ketika guru sedang melakukan pembelajaran tentang menu- lis karangan narasi baik pada kelompok eksperimen I, eksperimen II, dan kelompok kontrol. Pengamatan dilakukan dengan memfokuskan pada tiga hal yaitu kegiatan pembukaan, kegiatan inti, dan kegiatan penutup. Berikut disajikan hasil pengamatan aktivitas guru kelompok eksperimen I, kelompok eksperimen II, dan kelompok kontrol di tabel 8 .

Tabel 8. Hasil Pengamatan Aktivitas Guru

\begin{tabular}{ccccc}
\hline Kelompok & Pembukaan & Inti & Penutup & Total \\
\hline Kontrol & 1,55 & 9,27 & 1,38 & 12,27 \\
Eksperimen I & 2,27 & 16,5 & 1,83 & 20,66 \\
Eksperimen II & 2,6 & 16,16 & 1,55 & 20,11 \\
\hline
\end{tabular}

Dari tabel 8 dapat dilihat bahwa rata-rata guru di kelas ekperimen I dan II lebih tinggi daripada kelas kontrol. Hal ini menunjukkan bahwa guru terlihat sangat terbantu dan mulai konsisten dalam menerapkan pembelajaran dengan menggunakan SSP tematik-integratif baik kegiatan pembukaan, kegiatan inti, dan penutup. SSP tematik-integratif membantu guru mewujudkan proses pembelajaran yang bermakna dan mendidik sehingga siswa belajar dua hal secara bersamaan yaitu pengetahun (hard skill) dan soft skill yaitu karakter disiplin dan tanggung jawab.

Sebelum dilakukan analisis data, terlebih dahulu dilakukan uji persyaratan analisis data yang terdiri dari uji normalitas sebaran data dan uji homogenitas varian. Hasil uji normalitas sebaran data karakter disiplin disajikan berikut ini.
Tabel 9. Rangkuman Hasil Uji Normalitas Karakter Disiplin

\begin{tabular}{cccc}
\hline & $\begin{array}{c}\text { Kolmogorov- } \\
\text { Smirniov }\end{array}$ & Sig. & \\
\hline Pretest & & & \\
Kontrol & 0,950 & 0,328 & Sig $>0,05$ \\
Eksp 1 & 0,766 & 0,601 & $=$ normal \\
Eksp II & 0,795 & 0,552 & \\
Posttest & & & \\
Kontrol & 0,867 & 0,440 & Sig $>0,05$ \\
Eksp I & 0,819 & 0,513 & $=$ normal \\
Eksp II & 0,741 & 0,642 & \\
\hline
\end{tabular}

Hasil perhitungan uji normalitas sebaran data menunjukkan nilai signifikansi $>0,05$. Dengan demikian, sebaran data pretest dan posttest karakter disiplin kelompok kontrol dan kelompok eksperimen (I dan II) berdistribusi normal. Data tersebut telah memenuhi syarat untuk dianalisis.

Hasil uji normalitas sebaran data karakter tanggung jawab disajikan di tabel 10. 
Tabel 10. Rangkuman Hasil Uji Normalitas Karakter Tanggung Jawab

\begin{tabular}{cccc}
\hline & $\begin{array}{c}\text { Kolmogorov- } \\
\text { Smirniov }\end{array}$ & Sig. & \\
\hline Pretest & 0,687 & 0,732 & Sig > 0,05 \\
Kontrol & 0,797 & 0,548 & $=$ normal \\
Eksp 1 & 0,751 & 0,626 & \\
Eksp II & & & \\
Posttest & 0,856 & 0,456 & Sig > 0,05 \\
Kontrol & 0,838 & 0,484 & $=$ normal \\
Eksp I & 0,796 & 0,551 & \\
Eksp II & & & \\
\hline
\end{tabular}

Hasil perhitungan uji normalitas sebaran data menunjukkan nilai signifikansi $>0,05$. Dengan demikian, sebaran data pretest dan posttest karakter tanggung jawab kelompok kontrol dan kelompok eksperimen (I danII) berdistribusi normal. Data tersebut telah memenuhi syarat untuk dianalisis.

Hasil perhitungan uji homogenitas varian data pretest dan posttest karakter disiplin kelompok kontrol dan kelompok eksperimen I, dan kelompok eksperimen II disajikan dalam tabel 11.

Tabel 11. Rangkuman Hasil Uji Homogenitas karakter disiplin

\begin{tabular}{cll}
\hline & Sig. & \\
\hline Kontrol \& Eksp I & 0,270 & Sig $>0,05=$ homogen \\
$\begin{array}{c}\text { Pretest } \\
\text { Posttest }\end{array}$ & 0,632 & \\
Kontrol \& Eksp II & 0,133 & Sig > 0,05 = homogen \\
$\begin{array}{c}\text { Pretest } \\
\text { Posttest }\end{array}$ & 0,892 & \\
\hline
\end{tabular}

Hasil perhitungan uji homogenitas karakter disiplin menunjukkan bahwa data memiliki nilaisignifikansi lebih besar dari 0,05. Dengan demikian, pretest dan posttest karakter disiplin kelompok kontrol dan eksperimen adalah homogen.

Hasil perhitungan uji homogenitas varian data pretest dan posttest karakter disiplin kelompok kontrol dan kelompok eksperimen I, dan kelompok eksperimen II disajikan dalam tabel 12.

Tabel 12. Rangkuman Hasil Uji Homogenitas karakter Tanggung Jawab

\begin{tabular}{ccc}
\hline & Sig. & \\
\hline Kontrol \& Eksp I & 0,906 & Sig > 0,05 \\
Pretest & 0,652 & $=$ homogen \\
Posttest & & \\
Kontrol \& Eksp II & 0,924 & Sig > 0,05 \\
Pretest & 0,897 & $=$ homogen \\
Posttest & & \\
\hline
\end{tabular}

Hasil perhitungan uji homogenitas karakter tanggung jawab di atas menunjukkan bahwa data memiliki nilai signifikansi lebih besar dari 0,05 . Dengan demikian, pretest dan posttest karakter tanggung jawab kelompok kontrol dan eksperimen adalah homogen

Berdasaran hasil perhitungan uji prasyarat statistik inferensial nampak data berdistribusi normal dan variansi ketiga kelompok adalah homogen. Dengan demikian uji statistik yang sesuai untuk menguji hipotesis adalah Anovasatu jalur.

Uji ANAVA dipilih untuk mengetahui perbedaan skor rata-rata karakter disiplin dan tanggung jawab yang signifikan di antara kelompok kontrol, kelompok eksperimen I, dan kelompok eksperimen II. Uji ANAVA yang digunakan adalah Analisis Variansi Satu jalur yaitu analisis variansi yang hanya menguji satu faktor variabel independen dalam penelitian.

Hasil uji Anova karakter disiplin siswa kelas III saat pretest dan posttest pada kelompok kontrol, kelompok eksperimen I dan kelompok eksperimen II dapat dilihat di tabel 13.

Tabel 13. Hasil Anova Karakter Disiplin

\begin{tabular}{ccc}
\hline & F & Sig. \\
\hline Total Pretest & 1,555 & 0,217 \\
Total Posttest & 18,173 & 0,000 \\
Total Peningkatan & 9,416 & 0,000 \\
\hline
\end{tabular}

Tabel 13 menunjukkan bahwa nilai signifikansi pretest karakter disiplin pada kelompok kontrol, eksperimen I, dan eksperimen II sebesar 0,217. Nilai signifikansi tersebut lebih besar dari taraf signifikansi yang telah ditentukan yakni 0,05 maka dapat disimpulkan bahwa tidak ada perbedaan siginifikansi karakter disiplin pada kelompok kontrol, eksperimen I, dan eksperimen II pada saat pretest.

Pada saat posttest diketahui nilai signifikansinya 0,00 . Nilai signifikansi 0,00 tersebut lebih kecil dari taraf signifikansi yang telah ditentukan yakni 0,05. Dapat disimpulkan bahwa ada perbedaan signifikansi karakter disiplin pada kelompok kontrol, eksperimen I, eksperimen II.

Hasil perhitungan Anova tentang pengaruh SSP tematik-integratif terhadap karakter disiplin siswa kelas III SD se-gugus 2 Kecamatan Banguntapan diperoleh nilai signifikansi $0,000<0,05$ sehingga dapat disimpulkan bahwa penggunaan SSP tematik-integratif berpengaruh signifikan terhadap penanaman karakter disiplin siswa kelas III SD se-gugus 2 Kecamat- 
an Banguntapan. Siswa yang diberikan perlakuan menggunakan SSP tematik-integratif menunjukkan skor karakter disiplin yang lebih tinggi dibandingkan siswa yang yang diberikan pembelajaran menggunakan perangkat pembelajaran tematik.

Indikator karakter disiplin yang mengalami peningkatan skor pada kelompok eksperimen I dan eksperimen II antara lain masuk ke kelas sebelum bel masuk berbunyi, mengenakan seragan dan perlengkapan sekolah dengan lengkap, duduk pada tempat yang telah di tentukan, menjaga kerapian seragam sekolah, mengerjakan PR dan mengumpulkannya di tempat yang ditentukan, melakukan pengamatan/percobaan/ membaca teks bacaan sesuai aturan, mendengarkan materi pembelajaran dengan tertib, mengerjakan tugas tanpa mengobrol atau bermain hingga selesai, mengantri untuk mengambil dan mengembalikan peralatan belajar milik sekolah, menyelesaikan tugas mandiri pada waktu yang ditentukan, membuang sampah pada tempatnya, dan merapikan sendiri kursi dan meja yang sudah digunakan.

Hasil uji Anova karakter tanggung jawab siswa kelas III saat pretest dan posttest pada kelompok kontrol, kelompok eksperimen I dan kelompok eksperimen II dapat dilihat di tabel 14.

Tabel 14. Hasil Anova Karakter Tanggung Jawab

\begin{tabular}{ccc}
\hline & F & Sig. \\
\hline Total Pretest & 2,129 & 0,125 \\
Total Posttest & 17,809 & 0,000 \\
Peningkatan & 10,669 & 0,000 \\
\hline
\end{tabular}

Tabel 14 menunjukkan bahwa nilai signifikansi pretest karakter tanggung jawab pada kelompok kontrol, eksperimen I, dan eksperimen II sebesar 0,125. Nilai signifikansi tersebut lebih besar dari taraf signifikansi yang telah ditentukan yakni 0,05 maka dapat disimpulkan bahwa tidak ada perbedaan siginifikansi karakter disiplin pada kelompok kontrol, eksperimen I, dan eksperimen II pada saat pretest.

Pada saat posttest diketahui nilai signifikansinya 0,00 . Nilai dignifikansi 0,00 tersebut lebih kecil dari taraf signifikansi yang telah ditentukan yakni 0,05. Dapat disimpulkan bahwa ada perbedaan signifikansi karakter disiplin pada kelompok kontrol, eksperimen I, eksperimen II.

Hasil perhitungan Anova tentang pengaruh SSP tematik-integratif terhadap karakter tanggung jawab siswa kelas II SD se-gugus 2
Kecamatan Banguntapan diperoleh nilai signifikansi $0,000<0,05$ sehingga dapat disimpulkan bahwa penggunaan SSP tematik-integratif berpengaruh signifikan terhadap penanaman karakter tanggung jawab siswa kelas III SD segugus 2 Kecamatan Banguntapan. Siswa yang diberikan perlakuan menggunakan SSP tematikintegratif menunjukkan skor karakter tanggung jawab yang lebih tinggi dibandingkan siswa yang yang diberikan pembelajaran menggunakan perangkat pembelajaran tematik.

Indikator karakter tanggung jawab yang mengalami peningkatan baik pada kelompok eksperimen I maupun eksperimen II antara lain membuang sampah pada tempatnya, menjaga kebersihan seragam dan perlengkapan sekolah, mengerjakan tugas mandiri atau kelompok sesuai petunjuk dan sesuai kemampuannya, melakukan percobaan, pengamatan, atau membaca teks bacaan sesuai dengan petunjuk dan sesuai aturan, merawat, mengembalikan dan merapikan peralatan belajar milik sendiri dan sekolah di tempat semula, berbicara dengan kata-kata yang sopan dan baik, mengerjakan tugas dan mendengarkan penjelasan guru tanpa bermain atau berbincang dengan teman.

Temuan tersebut didukung oleh pernyataan Schmidt, et. al (2009, p.125) bahwa:

\section{Pedagogical content knowledge refers to the content knowledge that deals with the teach- ing process. Pedagogical content knowledge is different for various content areas, as it blends both content and pedagogy with the goal being to develop better teaching prac- tices in the content areas.}

Artinya PCK berhubungan erat dengan proses pembelajaran yang mendidik. PCK berusaha memadukan unsur pembelajaran dan ilmu mendidik dengan tujuan mengembangkan praktek pengajaran yang lebih komprehensif dan berkualitas baik perencanaan kegiatan, media, materi, metode, maupun penilaian pembelajaran sehingga terbentuklah aspek kognitif, afektif, dan perkembangan moral dari individu.

Temuan tesebut juga dukung dengan pernyatan Howe (1991, pp.6-7) sebagai berikut:

A thematic teaching give these learning processes encompass knowledge concepts, and skills related to development of aesthetic, affective skills, cognition, language, physical skills, social skills, construction skills, and pretend play skills. Affective skills as self awareness, decision making, independence, 
self confidence, positive self esteem. Social skills is like internal behavior controls, successful patterns of interaction, cooperative attitudes and actions, helpful attitudes and actions, responsible attitudes action and action, appreciation and respect for individual and cultural similarities and differences, respect for the environment.

Artinya, pembelajaran tematik memberikan proses pembelajaran yang mengajarkan tentang konsep, pengetahuan, dan keterampilan yang berkaitan dengan pengembangan estetika, keterampilan afektif, kognitif, bahasa, keterampilan fisik, keterampilan sosial, keterampilan konstruksi, dan keterampilan bermain. Keterampilan afektif yang dimaksud seperti kesadaran diri, pengambilan keputusan, kemandirian, kepercayaan diri, harga diri yang positif. Sedangkan keterampilan sosial yang dimaksud seperti pengendalian sikap dan perilaku (disiplin), pola interaksi yang baik, sikap dan tindakan yang kooperatif, sikap dan tindakan yang suka membantu, sikap dan tindakan yang bertanggung jawab, menghargai dan menghormati persamaan dan perbedaan individu dan budaya, dan menghargai lingkungan hidup.

Hasil temuan dari penelitian ini dan dukungan fakta empiris menyatakan bahwa SSP tematik-integratif memberikan pengaruh yang lebih baik dan secara signifikan meningkatkan karakter disiplin dan tanggung jawab siswa sekolah dasar kelas III. Temuan ini menuntut guru untuk lebih kreatif dan inovatif dalam menggunakan SSP tematik-integratif sebagai perangkat pembelajaran yang lebih mendidik di dukung dengan pendekatan saintifik dan metode penanaman nilai karakter mampu menumbuhkan motivasi untuk belajar, berbuat baik, mencapai keberhasilan, memiliki harga diri yang baik sehingga siswa memiliki sikap dan perilaku disiplin dan tanggung jawab yang lebih baik terhadap prestasi belajar.

\section{Simpulan dan Saran}

Simpulan

Berdasarkan hasil penelitian dan pembahasan yang telah disampaikan sebelumnya dapat disimpulkan bahwa: (1) Penggunaan SSP tematik-integratif dalam proses pembelajaran berpengaruh signifikan terhadap penanaman karakter disiplin siswa kelas III SD se-gugus 2 Kecamatan Banguntapan. Hal ini ditunjukkan dengan hasil uji Anova posttest karakter disiplin menunjukkan nilai $\mathrm{F}$ sebesar 18,173 dengan $\mathrm{db}$
86 dan taraf signifikansi 0,00. Nilai signifikansi lebih kecil dari nilai alpha yang ditetapkan yaitu 0,05. (2) Penggunaan SSP tematik-integratif dalam proses pembelajaran berpengaruh signifikan terhadap penanaman karakter tanggung jawab siswa kelas III SD se-gugus 2 Kecamatan Banguntapan. Hal ini ditunjukkan dengan hasil uji Anova posttest karakter tanggung jawab menunjukkan nilai $\mathrm{F}$ sebesar 17,809 dengan $\mathrm{db}$ 86 dan taraf signifikansi 0,00 . Nilai signifikansi lebih kecil dari nilai alpha yang ditetapkan yaitu 0,05 .

Hasil uji Anova tersebut dapat disimpulkan bahwa terdapat pengaruh yang positif dan signifikan penggunaan SSP tematik-integratif terhadap penanaman karakter disiplin dan tanggung jawab siswa kelas III SD se-gugus 2 Kecamatan Banguntapan.

Saran

Berdasarkan temuan penelitian yang telah dilakukan, hasil penelitian ini dapat memberikan sumbangan pikiran dalam menanamkan karakter pada diri siswa. Beberapa saran sebagai usaha untuk lebih meningkatkan karakter siswa sebagai berikut: (1) SSP Tematik integratif dapat digunakan sebagai perangkat pembelajaran alternative dalam menanamkan karakter disiplin dan tanggung jawab bagi siswa SD kelas III. (2) Siswa hendaknya terbiasa mengikuti proses pembelajaran tematik-integratif dengan pendekatan saintifik yang menekankan pada penanaman karakter disiplin dan tanggung jawab. (3) Penggunaan SSP tematik-integratif berpengaruh terhadap karakter disiplin dan tanggung jawab. Maka disarankan kepada kepala sekolah untuk mengarahkan dan memfasilitasi guru dalam mengoptimalkan penggunaan SSP tematik-integratif dalam proses pembelajaran siswa SD kelas III. (4) Untuk penelitian lebih lanjut, dapat melakukan penelitian untuk mengetahui pengaruh SSP tematik-integratif terhadap nilai karakter lain dengan tema dan mata pelajaran tertentu pada jenjang pendidikan yang berbeda.

\section{Daftar Pustaka:}

Bohlin, K.E. (2005). Teaching character education through literature awakening the moral emagination in secondary classrooms. New York: RoutledgeFalmer.

Browne, A. (2009). Developing language and literacy 3-8. (3rd ed.). London: SAGE Publications Ltd. 
Clemes, H.\& Bean, R. (2001). Melatih anak bertanggung jawab. (Terjemahan Anton Adiwiyanto). New York: Penguin Putnam. (buku asli diterbitkan tahun 1978).

Crooks, R., L \& Stein, J. (1991). Psychology science, behavior, and life: second edition. San Fransisco: Harcourt Brace Jovanovich

Drake, S.M. (2012). Creating standards based integrated curriculum: the commom core state standards edition. California. Corwin Press A sage Publication Company.

Hergenhahn, B. R. \& Olson, M. H. (2012). Teori belajar edisi ketujuh. (Terjemahan Triwibowo). Jakarta: Kencana Prenada Media Group

Hosnan, M. (2014). Pendekatan saintifik dan kontekstual dalam pembelajaran abad 21. Bogor: Ghalia.

Howe, D., et all. (1991). Teaching young childeren using themes. United States of America: Good Years Book.

Joyce, B. \& Weil, M. (1996). Models of teching fifth edition. Boston. Allyn and Bacon.

Kemdikbud. (2013). Peraturan Menteri pendidikan Nasional dan Kebudayaan RI No 67 Tahun 2013 tentang standar proses pendidikan dasar dan menengah.

Kemdiknas. (2009). Peraturan Menteri Pendidikan Nasional RI No 8 Tahun 2009, tentang Program Pendidikan Profesi Guru Prajabatan.

Koesoemo, A. D. (2007). Pendidikan karakter: strategi mendidik anak di zaman global. Jakarta: Gramedia.

Lickona, T. (1991). Educating for character: how ous schools can teach respect and responbility. New York: Bantam Books.

Margo, D. (2014). What is Subject specific Pedagogy: The teaching or learning of a specific subject. Di ambil pada tanggal 25 Juni 2014 darhttp://instaedu.com/what-is-Subjectspecific-Pedagogy/

Nucci, L. \&Narvaez, D. (2008). Handbook of moral and character education. New York: Routledge.

Randle, I. (2010). Themeasure of success: integrated thematic instruction. Diakses di http://www.tandfonline.com/doi/pdf/ pada tanggal 21 Juli 2013. Jam 22.13 WIB.

Renee, D. (2014). What is Subject specific Pedagogy: The teaching or learning of a specific subject. Di ambil pada tanggal 25 Juni 2014 dari http://instaedu.com/what-is-Subjectspecific-Pedagogy/

Rusman. (2010). Model-model pembelajaran: mengembangkan profesionalisme guru. Jakarta: Raja Grafindo.

Schunk, D. H. (2009). Learning theories an educational perspective 5th end. New Jersey: Pearson.

Slavin, R. E. (2008).Psikologi pendidikan Teori dan Praktik. Terjemahan oleh Marianto Samosir. Jakarta: Indeks.

Sugihartono, dkk. (2007). Psikologi Pendidikan. Yogyakarta: UNY Press.

Sukarjo. (2006). Kumpulan materi evaluasi pembelajaran. Yogyakarta: UNY

Suparno, P., dkk. (2003). Pendidikan budi pekerti untuk SMU-SMK.Yogyakarta: Kanisius.

Wibowo, Widodo Setiyo. (2011). Pengembangan Subject Spesific Pedagogy (SSP) berbasis domain aplikasi sains untuk menanamkan karakter siswa SMP. Tesis magister, tidak diterbitkan, Universitas Negeri Yogyakarta, Yogyakarta. 